\title{
Classic Oxidation of Alcohols Using Pyridinium Chlorochromate
}

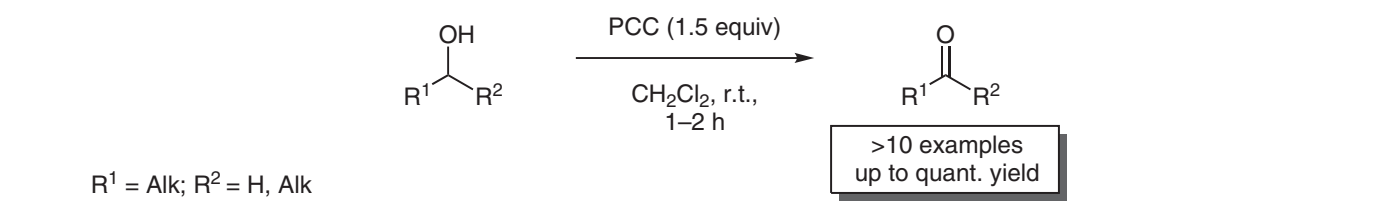

Selected examples:

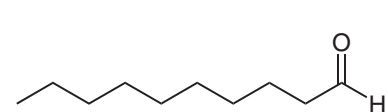

$92 \%$ yield<smiles>CCCCCCC=O</smiles>

$78 \%$ yield<smiles>O=CCCCCC=O</smiles>

$68 \%$ yield<smiles>CC(C=O)C1COC(C)(C)O1</smiles>

$85 \%$ yield<smiles>CC(C)(C)C1CCC(=O)CC1</smiles>

$97 \%$ yield<smiles>CC(C)=CCCC(C)CC=O</smiles>

$82 \%$ yield

( 0.3 equiv $\mathrm{NaOAc}$ was added)

one-pot reaction:
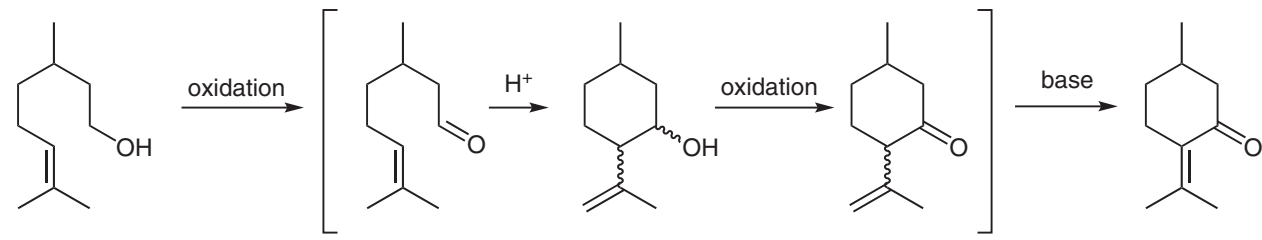

citronellol

pulegone

Significance: In 1975, Corey and Suggs developed the efficient oxidation of primary and secondary alcohols to the corresponding carbonyl compounds by treatment with pyridinium chlorochromate (PCC). The advantages of this method (also known as Corey-Suggs oxidation) are the simple procedure, efficiency, versatility and the prevention of over-oxidation. On the other hand, chromium(VI) compounds are toxic and must be handled with care.
Comment: Interestingly, the authors reported the preparation of pulegone in one step from citronellol using two subsequent oxidations.

\section{Category}

Metals in Synthesis

\section{Key words}

chromium compounds

oxidation

alcohols

aldehydes

ketones

\section{Synfact}

